\title{
ORFANDADE EXISTENCIAL: uma perspectiva contemporânea a partir do Mito de Prometeu
}

DOI: $10.22289 / 2446-922 X . V 2 N 2 A 2$

\author{
Baltasar dos Reis Faria \\ Alessander Freitas do Amaral ${ }^{1}$
}

\section{RESUMO}

O artigo investiga a relação entre os conceitos da tragicidade da existência, da imanência como sinônimo de vida excessivamente dedicada à busca cega por prazer e felicidade e do desenvolvimento científico e tecnológico com a orfandade existencial contemporânea. Tem como argumento e referencial as imagens simbólicas, oferecidas pelo Mito de Prometeu, que marcam o nascimento de um gênero literário, denominado Tragédia Grega, que entre outras coisas trata da existência nas instâncias divina e humana e seus conflitos. No diálogo entre o Mito e autores como Kierkegaard, com seu conceito de angústia e autenticidade da existência, pretende-se apontar para o papel importante destes fenômenos existenciais na perda da autenticidade, da subjetividade e na consequente orfandade ou desamparo atuais.

Palavras Chave: Vazio, Desamparo, Angústia, Existência.

\section{ABSTRACT}

The paper investigates the relationship between the concepts: tragedy of the existence, immanence - as a synonym of excessively life dedicated to the blind pursuit of pleasure and happiness and scientific and technological development with the contemporary existential orphanhood. Its argument and reference are based in the symbolic images offered by the Myth of Prometheus, which mark the birth of a genre called Greek Tragedy, which among other things deals with the existence in the divine and human instances and their conflicts. In the dialogue between the Myth and authors such as Kierkegaard, with his concept of anxiety and authenticity of existence, it is intended to point to the important role of these existential phenomena in the loss of authenticity, subjectivity and consequent orphanhood or current helplessness.

Keywords: Empty, Helplessness, Anguish, Existence.

\footnotetext{
${ }^{1}$ Endereço eletrônico de contato: alessanderf@netsite.com.br
}

Recebido em 05/09/2016. Aprovado pelo Conselho Editorial e aceito para publicação em 03/10/2016. 


\section{INTRODUÇÃO}

O presente trabalho tem por finalidade investigar, discutir e colocar em perspectiva a Orfandade Existencial contemporânea como produto da perda da consciência de que a vida é trágica posto que aponta para sua finitude. É ilusória visto que se busca, cegamente, satisfazer desejos de realização plena e feliz e, por fim é, frágil, uma vez que coloca sua fé na ciência e na tecnologia como uma espécie de fonte dessa realização, com nuances de uma super religião.

O termo orfandade, vem da palavra grega orphanós ${ }^{1}$, que significa literalmente desprovido, privado de. Já o termo existência, vem do termo em latim exsisto ${ }^{2}$, que aponta para um emergir-se, um mostrar-se, um elevar-se acima, para um sentido maior, com tudo o que isso implica: tensão e dúvida, esperança e medo, finitude e necessidade, desespero e humildade. A busca por esse sentido é, e sempre foi, uma das questões essenciais e centrais da história e mesmo com todos os avanços científicos-tecnológicos continua a mesma e ainda sem solução definitiva.

Trata-se de uma orfandade objetiva, que aponta para um ser desprovido de sentido, senão supercialmente, que não se manifesta, não emerge nas suas potencialidades, no estar no mundo e paradoxalmente, no ser maior do que o próprio mundo que o rodeia.

É fato que desde o grande desenvolvimento industrial no início do século XVIII, na Inglaterra, grandes mudanças ocorreram "[...] uma transformação em todas as relações"3. Novos valores, princípios e modos de pensar surgiram e mudaram radicalmente a vida dos indivíduos e impactou, de forma indelével, na forma de compreensão do eu. Entretanto, isso não foi e não é o bastante para saciar as razões mais profundas da existência humana. Ao 
contrário, produziram muito conhecimento, mas poucas e parcas relações subjetivas autênticas ${ }^{3}$.

O efeito, inesperado, portanto, foi o destronar do eu de si mesmo, expulsando-o para as bordas da existência (superficialidades) em um infindável nascer e morrer, como no castigo de Prometeu, que acorrentado a uma rocha em uma montanha distante, exposto ao sol escaldante e à lua fria, experimentava todos os dias os abutres o atacarem, rasgar suas entranhas e comer-lhe o fígado, que durante a noite crescia de novo e de manhã estava pronto para um novo ataque voraz. Conforme o Mito, isso acontecia porque Prometeu concedeu ao ser humano os benefícios destinados apenas aos deuses ${ }^{4}$.

O Mito de Prometeu, de Ésquilo (525-456), considerado o fundador da Tragédia Grega, está inserido no tempo da Atenas clássica, de Sócrates e de Xenofonte, de grandes escultores e arquitetos e situa-se como um dos mais antigos Mitos criados pelos gregos e remete à separação entre o mundo divino e o humano, à origem do fogo (ciência, conhecimento) e dos males humanos ${ }^{5}$.

Esse gênero se acentuou entre os gregos no começo do século V a.C. (480 a.C.), quando eclodia a segunda guerra greco-pérsica, e mostra a controvérsia entre Zeus e Prometeu. Em Ésquilo, o motivo da disputa era a relação de Prometeu com os mortais se apiedando deles, concedendo-Ihe presentes. Dentre esses a technê, técnica, que para Sócrates era "[...] um modo de buscar o conhecimento necessário para viver uma vida feliz e virtuosa"5, que lhe permitiram sair de uma condição limitada para uma condição similar à dos deuses, da escravidão para a liberdade plena, contrariando a vontade de Zeus.

Prometeu, então, roubou o fogo de Zeus e concedeu ao homem; retirou de sua memória a lembrança da morte e o alimentou de desejos cegos e inconsequentes como forma de redenção ${ }^{4}$. Os atos de Prometeu configuram, simbolicamente, a progressão do processo 
existencial que culminou na orfandade existencial contemporânea de que trata o presente trabalho - tempo de transformações, reacomodações e vazio.

Colocado em perspectiva na discussão, Kierkegaard aborda o tema da angústia fazendo eco à perda do sentido trágico da existência, como sendo a realidade da liberdade enquanto possibilidade, em que o sujeito se encontra afastado de uma dimensão transcendental 6 .

Ora, assim sendo, as fugas para o homem moderno parecem possíveis, pois há um afastamento quase completo da dimensão transcendental. Entretanto, no final essas fugas da realidade, apenas colocam o ser humano em movimentos circulares, trazendo-o sempre de volta ao ponto que se quer esquecer - ao que Kierkegaard chama de angústia ética ou a dicotomia entre liberdade e prisão - onde reside a angústia inevitável e indispensável à existência autêntica ${ }^{7}$, como um determinante existencial, que se manifesta na cotidianidade do estar-no-mundo, no lidar com o real e o imaginário, ${ }^{8}$ com o ser e o ter e, por fim, com o profano e o divino.

Além disso, o exercício de tentar negar a angústia ou a tragicidade da existência, suprimindo-a da consciência, acaba por força-la a apresentar-se com adereços ou patologizações novas - como lanças ainda mais pontiagudas ${ }^{9}$. Pode-se citar algumas dessas manifestações que, na atualidade parecem requerer esse lugar: desamparo, solidão, vazio, orfandade existencial, bipolaridades, síndrome do pânico e alguns tipos de depressão que, neste caso, não é a ausência do outro, mas a falta de uma unidade de si mesmo.

Percebe-se, portanto, uma progressão: da negação da angústia ou da tragicidade do existir, ao entorpecimento (individualismo narcísico); do entorpecimento ou ideal cego de uma vida desprovida da realidade do sofrimento e mal-estar, ao vazio ou orfandade existencial que é, exatamente uma vida imanente, sem qualquer nuance transcendental e espiritual, permeada por consumismos, compulsões e virtualidades.

Rev. Psicol Saúde e Debate. Jan., 2017:2(2):14-41. 
A angústia e o sentido trágico, apesar da tentativa de negação, possuem funções libertadoras, visto que ocorrem frente à possibilidade de escolha e somente esse confronto franco vai permitir ao homem o salto para o modo existencial que Kierkegaard descreveu como sendo a existência autêntica. Logo, o aspecto positivo da angustia é exatamente o de gerar autenticidade à existência que vai além do aqui e agora, da imediaticidade, de forma transcendente, posto que o homem traz dentro de si a chama da eternidade, pois é síntese de finito e infinito ${ }^{10}$. Portanto é preciso fazer um resgate do sujeito, valorizá-lo e trabalhá-lo em todas as dimensões, pensar no afetivo, no subjetivo e não só no prático, no mensurável, no observável11.

Assim, a partir do Mito de Prometeu, em diálogo com autores clássicos e modernos tais como: Kierkegaard, Freud, Heidegger, Sartre, May, Bubber, Baumam e outros, se propõe discutir e apresentar uma perspectiva filosófico-histórica do estado de Orfandade Existencial da atualidade e da sua relação direta como a perda do sentido trágico da existência, da tentativa de supressão da angústia e da frágil consciência de finitude e transcendência, na formação da pessoa da contemporaneidade, acorrentando-a em uma existência inautêntica, por isso compulsiva; com pouco ou quase nenhum conteúdo interno sólido. Um ser oco vivendo às margens, portanto órfão de si mesmo.

Para tanto, o desenvolvimento do artigo segue o seguinte caminho: 1) inicialmente pretende-se situar e contextualizar o Mito de Prometeu e definir termos como Orfandade e Existência; 2) situar, e colocar em perspectiva, no interior da analítica da existência, os temas da tragicidade e da angústia; 3) da imanência como sinônimo de desejos cegos e finalmente; 4) do desenvolvimento cientifico-tecnológico ocupando um papel antes delegado à religião, face às transformações da cultura e da sociedade atual, sobretudo, no que tange à despersonalização e ao desamparo.

Rev. Psicol Saúde e Debate. Jan., 2017:2(2):14-41. 


\section{METODOLOGIA}

O estudo foi realizado a partir de uma Revisão de Literatura conceitual, buscando referencial na base de dados do Scielo, no período compreendido de 1994 a 2015, por meio do cruzamento das palavras chaves: Vazio, Desamparo, Angústia e Existência.

Considerando as obras clássicas da filosofia existencial, devido a necessidade de contextualizar a filosofia, utilizou-se, em especial, o pensamento de Kierkegaard, filósofo dinamarquês do sec. XIX, precursor do Existencialismo como o primeiro pensador a se ocupar sistematicamente do problema da angústia como demarcadora da existência e da vida autêntica, como fruto de escolha, decisão e vontade, em contraposição ao hegelianismo e o conceito de mediação que não pressupõe liberdade, vontade e decisão. E Nietzsche, pensador alemão do sec. XIX, que se caracteriza pela afirmação múltipla, diversificada da vida, da existência e se distancia das tradicionais teorias filosóficas. Utilizou-se, principalmente, seu pensamento sobre o nascimento da tragédia em contraposição ao racionalismo socrático e o conceito de homem teórico. Outros autores como Freud, Heidegger, Sartre, May, Bubber e Baumam, também serão utilizados em algum momento, a fim de contribuir para elucidar a temática, resolver ou criar tensões e dar dinâmica ao trabalho.

\section{DESENVOLVIMENTO}

\subsection{A PERDA DO SENTIDO TRÁGICO DA EXISTÊNCIA E SEU IMPACTO NA SUBJETIVIDADE}

Para Nise da Silveira: "O mito é como uma espécie de trilha. Se você partir do mito, você chega onde quiser" ${ }^{12}$. Os Mitos e as Fábulas são assim, trilhas, como a Fábula de 
Hyginus, que ajuda a percorrer terenos árduos e escorregadios com profundidade e leveza ao mesmo tempo:

Angústia, ao atravessar um rio, viu uma massa de argila e, mergulhada nos seus pensamentos, apanhou-a e começou a modelar uma figura. Quando deliberava sobre o que fizera, Júpiter apareceu. Angústia pediu que ele desse uma alma à figura que modelara, e, facilmente, conseguiu o que pediu. Como Angústia quisesse dar o seu próprio nome à figura que modelara, Júpiter proibiu e prescreveu que lhe fosse dado o seu. Enquanto Angústia e Júpiter discutiam, Terra apareceu e quis que fosse o seu o nome daquela a quem fornecera o corpo. Saturno foi escolhido como árbitro. E este, equitativamente [sic], assim julgou a questão: tu, Júpiter, porque lhe deste a alma, tu a terás depois da morte. E tu, Terra, porque lhe deste o corpo, tu o receberás quando ela morrer. Todavia, porque foi Angústia quem primeiramente a modelou, que ela a tenha, enquanto viver. ${ }^{13}$

Como já foi sinalizado acima, os gregos foram exímios na arte dos Mitos e produziram dois dos maiores tragediólogos da civilização grega: Ésquilo (525-456), considerado o fundador da tragédia grega e autor de mais de oitenta peças e Sófocles ${ }^{14}$.

O mito é mais do que entretenimento: "Para nós, mitologia e história são duas coisas nitidamente separadas, mas não o eram para os gregos daquele tempo em que o próprio mito significava história" ${ }^{15}$, pois a tragédia leva ao palco as lutas internas e a insegurança diante de uma sociedade em transição ${ }^{16}$. No presente trabalho, o Mito de Prometeu será uma dessas trilhas - com suas imagens e simbolismos, através dos quais se investigará possíveis fontes e desdobramentos da orfandade ou vazio existencial da contemporaneidade - vislumbres das lutas internas e da insegurança da transição da modernidade para a pós-modernidade.

O tema desamparo, aqui denominado de orfandade é recorrente entre filósofos, teólogos, psicólogos, pensadores, antropólogos, sociólogos etc. Assim, Kierkegaard, Freud, Heidegger, Sartre, May, Bubber, Baumam, entre outros, trataram, em alguma medida, do Rev. Psicol Saúde e Debate. Jan., 2017:2(2):14-41. 
assunto e apresentaram percepções, sugestões, reflexões e constatações que tiveram impacto no seu tempo e posteriormente. Algumas dessas ideias convergem, outras divergem entre aqueles que se dedicaram a compreender melhor o fenômeno.

Kierkegaard, por exemplo, trouxe uma reflexão na perspectiva de que a orfandade ou o desamparo surge da insistência em se viver inautenticamente, fugindo da angústia ou da tragicidade da existência. Assim, para ele, o ser é fruto de escolhas, implicando, para tal, perder para ganhar, abandonar e responsabilizar-se pelo que escolheu e, por fim, ascender e transcender 10,17 .

Não há ascensão sem luta e luto. Por essa razão, para Kierkegaard há dois princípios importantes que usou para criticar o princípio da Mediação na dialética de Hegel, que, na sua percepção, esbarrava exatamente na questão crucial da existência autêntica: a escolha. O primeiro trata da questão de que o ser humano não é um ser ideal, mas um existente, que a partir do temor e do tremor ousa ou não se tornar o que estava destinado a ser. Essa liberdade é derivada, fruto de uma liberdade onipotente que doando se retira para que o ser finito possa realizar-se. O segundo, por sua vez, refere-se à distinção entre o interior e o exterior, que para Kierkegaard não são idênticos. Sendo assim, a subjetividade, a fé e o amor, dimensões da interioridade, não se equivalem ou correspondem ao estado, à lei ou ao mercado, que são características do exterior como quer Hegel, na formação do sujeito ${ }^{18}$.

Portanto, o tornar-se o que se está destinado a ser, tem a ver com questões internas inerentes ao ser em construção e a partir de suas escolhas, mas do que de qualquer outro argumento. Isto porque "o homem é livre, capaz de autodeterminação em ato, livre do determinismo natural, sendo capaz de se libertar da essencialidade característica da natureza" 19 .

O princípio de Mediação de Hegel, como afirma Kierkegaard, ao contrário, possui validade insubstituível para diagnosticar e determinar o mundo físico, a natureza e a Lógica, Rev. Psicol Saúde e Debate. Jan., 2017:2(2):14-41. 
mas é insuficiente para conduzir o homem ao abismo, ao salto no escuro, ao encontro mais terrificante e transcendental que é possível, do eu consigo mesmo, do humano com o divino, do ser com a morte, que paradoxalmente não ocorrem na eternidade, mas no tempo.

Essa ruptura se dá, fundamentalmente, na distinção entre mediação e paradoxo e suas implicações nas concepções de objetividade e subjetividade. Na mediação o indivíduo singular não tem liberdade, vontade e decisão. Assim, Kierkegaard estabelece a dialética da descontinuidade, por entender, que a liberdade do concretizar da existência não obedece a leis lógicas, mas ao ato de liberdade que designa, ao existente, a tarefa de edificar-se a si mesmo ${ }^{18}$.

Conclui-se, que a concretização do si mesmo se dá a partir de um ato de vontade, de liberdade, de consciência e razão do indivíduo; a partir da angústia e não por necessidade lógica; por escolha e não por determinação ${ }^{18}$.

Não se pode ignorar, que haja, sim, uma carga racional e genética impulsionadas pelas necessidades na formação e sustentação da posição subjetiva. Porém esses, são coadjuvantes e não os protagonistas ${ }^{20}$.

Corrobora com o pensamento de Kierkegaard, a reflexão de May de que a perda do sentido trágico da vida humana desembocou na crença exagerada na importância do indivíduo e de sua razão que, com o tempo, o esvaziou da própria consciência de existência o entregando ao determinismo biológico social. Isto porque o sentido trágico da existência, indica que levamos a sério a liberdade e a necessidade, demonstrando nossa fé na "vontade indestrutível do homem para realizar sua humanidade" ${ }^{21}$ e que, ao contrário, a ansiedade existencial resulta das tentativas reiteradas do indivíduo de negar ou diminuir a ansiedade associada ao confronto com os dados existenciais, tais como a negação da morte e da liberdade de escolha, evitando as responsabilidades, ou seja, fazendo escolhas inautênticas e pouco corajosas ${ }^{22}$.

Rev. Psicol Saúde e Debate. Jan., 2017:2(2):14-41. 
Ressalta-se que o sentido trágico aqui não é sinônimo de determinismo biológico, psicossocial ou religioso. Ao contrário, trata-se de uma condição inerente ao existir que transcende a própria fisicalidade temporal.

Talvez ninguém tenha colocado tão bem a importância da tragédia como os gregos e de como ela tem o poder de humanizar e empurrar o ser humano para além do estado de imanência estática; de aproximar e estabelecer uma nova ótica de si e do outro, pois como afirma Bowra, se referindo aos gregos, "[...] uma das funções da tragédia era apresentar de forma concreta problemas relativos ao homem e às suas relações com os deuses ou as relações dos homens entre si" ${ }^{23}$ ou "impressionar e transtornar os espíritos, agindo sobre os corações com uma potência misteriosa" ${ }^{14}$.

Historicamente, pode-se aludir que o surgimento das grandes nações e realizações, ocorreram a partir das grandes tragédias ou da necessidade de transcender o status quo. Parece corroborar com essa ideia, a perspectiva do princípio de compensação de Adler que reforça o fundamento de que as vidas marcadas pela tragicidade, que pode conduzir ao fracasso, se considerada apenas em si mesma, pode, paradoxalmente, elevar o ser à transcendência, encorajando a transformação de fraqueza em força. Ao contrário, aquelas superprotegidas acabam por não desenvolver uma consciência autentica de si e do outro ${ }^{24}$.

Óbvio que a tragicidade, a qual o trabalho trata, vai além das questões genéticas e biológica, tem a ver com a existência em plenitude - a angústia de se saber existente, que pode ser potencializada se esse existir for marcado por limitantes físicos ou biológicos. Portanto, não é uma questão de punir o culpado e absolver o inocente, é uma questão de existir ou não, pois "não há inocentes que não escapam que Ihes caia um raio na cabeça" ${ }^{14}$.

No Mito de Prometeu, essa questão fica demarcada quando é concedido ao ser humano o presente que o livrou da consciência de sua morte, fazendo o crer que se assemelhava aos deuses, imortal e eternamente feliz. Entretanto, ao invés de fortalece-lo, o 
fez, com o passar do tempo, se esconder e abrir mão de ser protagonista, herói, para se tornar coadjuvante da própria existência. Fato semelhante ocorre quando a serpente, na narrativa bíblica, concede à Eva e, esta a Adão, o fruto do bem e do mal, sendo achado, logo em seguida, escondidos entre os arbustos, tomados e paralisados pelo medo ${ }^{25}$.

Faz todo o sentido, levando-se em conta o fenômeno citado, que, como afirma Sartre, o homem tenha como objetivo - o ser deus. Aliás, esse foi o argumento usado pela serpente para induzir Adão e Eva a pecar: "ser igual a Deus"25. Entretanto, o homem faz isso exatamente para fugir da angústia de existir, por isso, Sartre assevera que o homem é uma tentativa fracassada de ser deus ${ }^{26}$.

Sartre afirma ainda que a existência se dá em completo abandono, ou seja, não há nada nem dentro, nem fora, que possa servir de sustentação e determinação de sentido, e que a busca externa da sustentação do ser é um agir de má-fé ${ }^{26}$.

As circunstâncias que envolviam o ser humano antes do presente de Prometeu, a saber a extinção da ideia da morte, sugere um ser das sombras, sem luz, sem ambições, preso ao fatalismo da existência para a morte determinada pelos deuses. Seria, este, um ser de má-fé, no sentido Sartreano? Habitante de uma sociedade de produção e não de consumo, de certezas e não de dúvidas, de submissão e apatia ao nada, pois não havia futuro, presente ou passado, só a nitidez de que a morte é certa e implacável? Talvez por isso, a arte que retrata a época era pulverizada de figuras horripilantes ligadas à morte, um ser das trevas com uma foice enorme, mostrando quão inútil era ter ambições, da qual se tentava fugir a todo custo. Talvez sim, essa pudesse ser uma atitude de má fé.

A questão da tragicidade da existência não é, "[...] portanto, mera literatura: se o trágico está presente na arte, não seria porque há tragicidade na vida?"14. Historicamente pode-se conectar essas circunstâncias ao período denominado de Era das Trevas.

Rev. Psicol Saúde e Debate. Jan., 2017:2(2):14-41. 
Desde a pré-história, os homens viram-se, afim de sobreviver, em constante necessidade de dispor do saber. Para isso, usou diversas maneiras formando um corpo que hoje é institucionalmente aceito como conhecimento científico ${ }^{27}$.

Com isso, a Era das Trevas, foi rejeitada filosófica, social e psicologicamente, estabelecendo uma nova ordem denominada de a era das luzes - o lluminismo, e posteriormente de a era da tecnologia, na qual encontra-se agora a sociedade contemporânea e onde é cada vez mais difícil morrer e ser infeliz. É como se fosse proibido existir em incompletude, frente a tantos subterfúgios. Porém, paradoxalmente, esse é um mundo vazio de sentido, marcado pelo tédio, no qual não mais se é permitido ficar triste e chorar ${ }^{28}$ e morrer deixa de ser um fato natural para ser uma estratégia para se livrar da angústia de viver ${ }^{29}$.

Em um mundo assim, recheado de ilusão e inautenticidade, mas que continua inóspito, a morte passa a ser desejada como um presente dos deuses, ao reverso do que Prometeu ofereceu no Mito. Agora o desejo é saber quando a morte chegará e muitos vão ao encontro dela para encurtar a espera. Uma vida sem a consciência de sua tragicidade, que não suporta a incompletude e o processo de construção existencial, enamora com o que Freud denominou de Pulsão de Morte ${ }^{30}$ e o suicídio parece ser uma saída honrosa como forma de vencer o demônio do vazio que habita a alma.

Isso porque como disse Kafka: "O homem não é somente uma obra da natureza, mas uma obra do próprio homem, um ser demoníaco, que transgredi constantemente os limites que Ihe são impostos" ${ }^{31}$. Outrora o limite era a morte, logo, se buscava negá-la, e não haveria presente melhor do que riscá-la da mente. Foi exatamente o que Prometeu fez, transgrediu o status quo e a ordem, riscando a consciência da morte. No presente, parece que o limite é a vida, então, passou-se a negá-la. Conclui-se, disto, que o presente aguardado agora é a morte, pois a tragédia passou a ser a vida.

Rev. Psicol Saúde e Debate. Jan., 2017:2(2):14-41. 
Ora, sendo assim, parece conveniente as palavras a seguir que captam bem o enunciado em questão.

A tragédia é mensagem de renúncia, de negação do querer viver. Ela é uma arte superior, pois representa o conflito da vontade consigo mesma em todos os fenômenos da existência humana. Mostra as dores sem número, as angústias da humanidade, o triunfo dos maus, o vergonhoso domínio do azar e do fracasso a que fatalmente estão condenados os justos e os inocentes. [...] Ela nos encaminha para uma decisão ética de desapego ${ }^{32}$.

Mas que tipo de desapego? Seria o desapego das certezas e das realizações absolutas e indolores da vida? Sim! Neste aspecto, segundo Nietzsche, os gregos devem servir como nossos luminosos guias, pois para eles a tragédia era uma necessária beberagem curativa, ou seja, algo de sabor intragável como os remédios amargos, que a civilização contemporânea faria bem em ressuscitar para curar-se de sua própria cultura ressecada pelo socratismo, a saber uma espécie de consolação racional otimista, porém vazia ${ }^{33}$.

Seguindo, a trilha kierkegaardiana, do paradoxo e do absurdo, pode-se afirmar, por fim, que o que mata é o que também cura e não é a mediação proposta por Hegel que tenta pacificar o que não se pode pacificar, mas a tragicidade que não pode ser apaziguada, apenas vivida como essencial ao existir em verdade e autenticidade.

\subsection{A PERDA DA CONSCIÊNCIA: O HOMEM DAS SOMBRAS, SEM SUBSTÂNCIA.}

A perda do sentido trágico gestou, aquilo que Nietzsche chamou de homem teórico, ou como enunciado, o homem das sombras, sem substância, que equipado com assombrosa força cognitiva, trabalha a serviço da ciência, cujo expecto ou tronco ancestral seria Sócrates. Todos os meios educativos trazem, originariamente, esse ideal em vista - a 
saber, criar o homem que privilegia apenas um único e infalível modo de conhecer, denominando como conhecimento, apenas aquele que derivar da mente lógico-racional ${ }^{34}$.

Este homem seria, para Nietzsche, "uma profunda representação ilusória" a “inabalável fé de que o pensar, pelo fio condutor da causalidade, atinge até os abismos mais profundos do ser" e "[...] está em condições, não só de conhecê-lo, mas inclusive de corrigi-lo [...]". Sendo assim, Sócrates seria ao erigir, em ideal, o homem teórico, a configuração do opositor mais ilustre à consideração trágica do mundo (4).

As tragédias, ao contrário, nos persuadem a refletir que diante da realidade de imperfeitos e mortais, rodeados pelo testemunho da inocente infelicidade de muitos, "a única verdadeira loucura é considerar este mundo como racional" e que pelo, veio da razão ou da negação, se pode reorganizá-lo, melhor do que se fez até este momento ${ }^{14}$.

No mito de Prometeu isso se dá através da concessão do segundo presente, que é exatamente o que vai gerar a inocência cega de se poder viver sem tragédia, construindo um mundo perfeito a partir da própria razão, destruindo o místico, a dor e as limitações, em um infinito carrossel de felicidade e contentamento.

Libertado do sentimento de fatalidade que o debilitava, o ser humano podia, a partir dali, tentar alcançar qualquer objetivo. Em segundo lugar, Prometeu colocou na humanidade esperanças cegas, incentivou-a a ser mais do que era, a alcançar novos objetivos, a se superar, a ser ambiciosa. Mas esses incentivos eram cegos, sem direção, nem ligação com a realidade ${ }^{4}$.

A tragédia, não equivale a dizer que tudo não passa de um predispor contra a vida, ao contrário, como exclama Nietzsche, "É o encanto supremo, essa existência estimulante, cambiante, perigosa, sombria e às vezes banhada de sol! É uma aventura viver - tomem aí o partido que quiserem, ela sempre terá esse caráter! " 35; seja onde for e como for.

Rev. Psicol Saúde e Debate. Jan., 2017:2(2):14-41. 


\subsection{A CIDADE COMO METÁFORA DO HOMEM DAS SOMBRAS E DAS BORDAS.}

As metáforas podem representar poderosos pontos luminosos na vastidão escura. Assim, no descaminho do ser em relação a si mesmo, a cidade é um desses pontos. Nela, aos poucos, aquele padrão que atrelava o ser à sua substância, foi cedendo lugar para o ser como sinônimo de suas conquistas e posses, passando de uma vida precária para uma vida abundante e essa como sinônimo de existir, de realização e de felicidade. Assim, especialmente no período posterior à Segunda Guerra, houve a abertura do mundo e a sensação, quase palpável, de que tudo seria possível ${ }^{36}$.

Qual a lógica? A de que a partir de então os seres estariam aptos a saírem da casa das limitações e se transferirem para a casa das realizações e do prazer, delegando a esses, o fundamento da existência como num ato adolescente, quase que totalmente desassombrado, fazendo ecoar um refrão audível de que: se os deuses podiam, eles também, ignorando completamente o fato de que "tudo quanto nasce precisa estar pronto para um doloroso ocaso" 33 - referência aos mortais e não aos deuses.

A cidade é como um levantar de copos, brindando esta conquista, pois ela fornece a sensação que coloca, os antes escravos da dura realidade da morte, na ilusão da evolução sem limites; da existência em cavernas e choupanas para os palácios, cafés, shopping, grandes edifícios, diversão, liberdade, consumo e desenvolvimento ilimitado. Isto porque "Uma cidade é não só topografia mas também utopia, devaneios, ilusões [...]" ${ }^{37}$.

A cidade passa a refletir seus habitantes e se torna marcada pelos excessos gerados por egos infantilizados e capitaneados "pela profusão de objetos, informações, tecnologias, mensagens e imagens (estas principalmente de caráter publicitário)" 38 .

Rev. Psicol Saúde e Debate. Jan., 2017:2(2):14-41. 
A cidade, portanto, tem esse viés de revelar a alma e a consciência humana em todas as suas dimensões, incorporando-a em processos de produção em massa de novos habitantes à sua imagem e semelhança.

Desde o tempo de Dickens e Baudelaire, a cidade foi vista como cenário social e psicológico, simultaneamente produzindo e refletindo a consciência humana. É um modelo que no período do Modernismo assumiu com frequência um papel central. Na Dublin de Joyce, na Londres de Eliot e na Nova lorque de Dos Passos a cidade passou a ser um dos mais importantes personagens, determinando e ilustrando cada ação humana ${ }^{39}$.

À cidade, também, atribui-se o duplo papel de acolher e alimentar a inocência e a ilusão, tanto quanto de revelar o engano dessa tese e a sua face trágica. Assim descreve Luís da Silva, personagem de A Angústia de Graciliano Ramos: "Entro no quarto, procuro um refúgio no passado. Mas não me posso esconder inteiramente nele. Não sou o que era naquele tempo. Falta-me tranquilidade, falta-me inocência, estou feito um molambo que a cidade puiu demais e sujou" 39 .

A cidade e seus habitantes são por demais frágeis, revelando uma paisagem em crise de valores que marca a transição para a modernidade ou dessa para a pós-modernidade onde a confiança irrestrita na onipotência do sujeito do iluminismo é posta em xeque. Luís da Silva se vê em uma situação que lhe provoca um lamentável e auto corrosivo estado psicológico e nada lhe preenche o vazio da alma que o próprio mundo, o mesmo que encheu de expectativas, aprofundou. Nesse mundo "[...] a cidade burguesa é semantizada, de modo mais geral, através da metáfora da vitrine, o que também enfatiza a preponderância da aparência, do narcisismo e do superficialismo sobre a vivência mais profunda [...] ${ }^{39}$.

Perder a consciência da tragicidade da vida transmutou o homem para fora de si, para as bordas, ofertando-lhe a cidade como essa nova casa ou casca, onde a Rev. Psicol Saúde e Debate. Jan., 2017:2(2):14-41. 
superficialidade tornou-se o padrão da existência. Por isso ao invés de fortalece-lo, o fez, não apenas frágil, mas angustiado e sem esperança, órfão de si mesmo, mergulhado nos vícios do não existir, pois a cidade de Deus, nova Jerusalém, se transformou em Babel polifônica, cujo produto é a multidão tumultuosa, estranha e temível ${ }^{39}$. Muito bem retratada nos livros $A$ Angústia e Cidade de Deus ${ }^{40}$.

A cidade se formou como uma espécie de abrigo ou escudo protetor do homem, mas essa camada protetora foi obtida a custo de uma maximalização da luta intramuros [...] A cidade, em si mesma, é tradicionalmente uma arma militar, um escudo ou armadura coletiva, uma extensão do castelo de nossa própria pele [... ${ }^{37}$.

Uma casa longamente desabitada é refúgio de bichos, sujeira e monstros. O desafio, portanto, é retomá-la. Para isso será necessário desalojar os atuais moradores e trazer de volta o verdadeiro morador. Este é o estado do homem das bordas que tenta se encontrar e acomodar na vastidão das exterioridades, onde parece habitar também a felicidade dos deuses, como no mito de Prometeu ${ }^{4}$. Mas na vastidão exterior só pode ser encontrada a sombra do ser, que mesmo que o delineei, não pode dar conta da sua integralidade e conteúdo.

Isto porque, há um ser em movimento, como diz Lévinas, em sua ética da alteridade. O ser no mundo, um eu recolhido em sua morada, vivendo de gozo e, por outro lado, um eu em movimento que constitui o mundo onde ele vive, onde localiza sua morada que é produzido a partir da originalidade da sua morada, pois "não se pode haver sentido no ser senão aquele que não se mede pelo Ser" ${ }^{41}$.

A cidade não é a morada original do ser, é lugar onde o ser que se habita vive e experimenta sua transformação e não sua transmutação, pois tanto o ser quanto o lugar que habita fora de si, ou nas bordas de si, é medido pela qualidade e autenticidade da sua autoconstrução, do conteúdo interno, que se expressa de dentro para fora.

Rev. Psicol Saúde e Debate. Jan., 2017:2(2):14-41. 
Portanto, não pode haver qualquer tipo de paz ou alívio para quem é estrangeiro em sua própria existência. A angústia, é este estado de fuga de si mesmo, pois o ser humano é o único capaz de angustiar-se e de ter coragem na sua existência e a tragédia que mata ao invés de elevar está, justamente, nas tentativas reiteradas e corajosas do humano de escapar das dores de seu existir ${ }^{42}$, sem contudo produzir mais do que meros devaneios de prazer.

\subsection{A TECNOLOGIA COMO A NOVA RELIGIÃO OU MAGIA DO HOMEM DAS BORDAS.}

As tecnologias podem manter o ideal de liberdade e autonomia do ser da razão, dando a entender que tudo poderá ser consertado ou mudado, como num passe de mágica, mas elas, em grande medida, apenas o manterá como um estrangeiro morando num casulo chamado existência, vagando como um jogador que sempre espera ganhar a fortuna que irá mudar sua vida, externa, na próxima jogada ou no próximo pacote de atualizações, entretanto, se encontra quase sem fichas, pois o HD já está sobrecarregado e travado da mesma e angustiante inexistência.

É o pensamento mágico que governa o consumo, é uma mentalidade sensível ao miraculoso que rege a vida cotidiana, é a mentalidade primitiva, no sentido em que foi definida como baseada na crença de onipotência dos pensamentos ${ }^{38}$.

De fato, a tecnologia, como grande massificadora que é, opera em duas frentes devastadoras do ser, pois ao suprimir a identidade das pessoas, suprimiu também a significação delas para consigo mesmas ${ }^{43}$.

O ser humano contemporâneo é um sujeito frágil, subjugado pela sua própria criação e que a cada novo avanço científico-tecnológico se torna mais dependente de sua produção. Esta fragilidade, esta dependência do homem na contemporaneidade se contrapõem ao que

Rev. Psicol Saúde e Debate. Jan., 2017:2(2):14-41. 
se esperava concretizar com a racionalidade e o humanismo apregoados ${ }^{41}$.

Está foi a descoberta da personagem Luís da Silva e possivelmente a de uma legião de outros que se encontram dependentes e fragilizados, não conseguindo se libertar da tecnologia, a nova religião mágica, que surgiu depois da falência dos deuses, que a despeito da propaganda, seu objetivo não parece ser libertário, ao contrário, é o de puir e zumbizar, tirando toda a substância do ser mantendo-o na borda da existência.

A consequência direta dessa totalidade imposta pela nova religião é uma sociedade, na qual, o sujeito encontra-se enclausurado em si mesmo, preso ao seu desejo de poder, prazer irresponsável e de produção de consumo, mas sem realização perene aguardando que a mágica ainda aconteça ${ }^{38}$. Entretanto o avanço técnico e científico se mostra, gradativamente, insuficiente na suplantação da superstição religiosa, mesmo na sua condição de futuro de uma ilusão ${ }^{44}$.

A perca do sentido trágico da vida levou o ser humano a julgamentos, crenças e atitudes despersonalizantes, cegas e destrutivas, ignorando que essas mesmas atitudes acabariam por acorrenta-los, assim como aconteceu a Prometeu, em uma espécie de existência bipolar - crescer e se desenvolver pela manhã, ter suas vísceras comidas ao longo do dia e morrer de angústia no final do dia, sentado num trono vazio de um reino sem fim, de uma existência no 'presente absoluto', sem universos simbólicos e transpessoais.

O mito de Prometeu, com o rompimento entre o humano e o divino, marca a passagem para o Narcisismo. Daqueles que como Prometeu são capazes de arriscar a própria vida pelo outro, para aqueles, Narcisos, que fazem dos outros, apenas objeto para alcançar prazer e realização individual. Neste caso é o outro que morre. Por isso, o espelho para a 
humanidade agora não é Prometeu, mas Narciso. "[...] O narcisismo abole o trágico e aparece como uma forma inédita de apatia [...] ${ }^{45}$.

Por fim, não poderia ser outra a consequência, que conforme a metáfora de que ostra feliz não faz pérola, entramos na era da escassez de pérolas, porque as ostras estão todas, insuportavelmente, felizes, perderam a capacidade de transformar tragédia no tipo de beleza que torna a existência suportável. Visto que a felicidade é um dom que deve ser simplesmente gozado, pois não cria, não produz beleza, ao contrário, são os que sofrem que a produz, não para eliminar a tristeza, mas para tornar o existir suportável ${ }^{46}$.

\subsection{UM TRONO VAZIO, OCUPADO POR QUEM NÃO TEM O SEU TAMANHO}

Prometeu completando sua trilogia de presentes, roubou o fogo de Zeus e concede ao ser humano. Com esse ato, zombou dos deuses e os tornou obsoletos, deixando um trono vazio, mas não por muito tempo. Agora, estava consumado, nascia o novo homem - deus de si mesmo, que logo ocuparia o trono vazio e usurpado.

Embora, amaldiçoar os deuses e Ihes destronar pareceu simples, riscá-los da memória, nem tanto. Kierkegaard, testemunhando sobre o ato do pai de amaldiçoar a Deus disse:

Que pavoroso para o homem que, como menino cuidando de carneiros nas campinas de Jylland, sofrendo dores, faminto e exausto, certa vez pôs-se sobre uma colina e amaldiçoou Deus - e o homem era incapaz de esquecer isso quando já tinha oitenta e dois anos ${ }^{47}$.

Pode-se notar que o fato de que, tanto no caso do pai de Kierkegaard quanto no dos seres humanos do Mito de Prometeu, o ato de amaldiçoar, abandonar ou zombar de Deus ou dos deuses, pareceu ter rendido imediatos bônus. Michael Pedersen Kierkegaard, pai de Rev. Psicol Saúde e Debate. Jan., 2017:2(2):14-41. 
Kierkegaard, por exemplo, se tornou o homem mais rico de Copenhagen e nada externo parecia atingi-lo. Os libertos de Prometeu, por sua vez, ao olharmos para a história, conquistaram fama, riqueza, conhecimento e magia, através da ciência e da tecnologia que aos poucos se tornou a "[...] negação mágica e definitiva da rareza" ${ }^{38}$.

Não se pode negar, portanto, que desde o advento do lluminismo, o mundo e seus habitantes ilustres, atingiram grandes feitos. E isso pode, realmente, dar a impressão de que os fracassos anteriores eram por culpa e responsabilidade de Deus ou dos deuses ${ }^{48}$.

Mas, nenhum trono permanece vazio por muito tempo, aliás nem chega a esfriar, e quem o ocupa, ganha o status de quem o ocupava anteriormente, neste caso o status de Deus, cujas exigências serão compatíveis com as prerrogativas do cargo - o problema parece ser que o trono foi feito sob medida, logo possui o tamanho exato de seu ocupante original.

Assim, a maldição agora não é a da falta, da abnegação, mas a da abundância; não dá subserviência, mas do poder e afirmação ${ }^{45}$. Tomar o lugar dos deuses não apenas deixou um trono vazio, porque o posto exigia um Deus e não um ser mortal, mas tornou a existência vazia de transcendência, encerrada em um ciclo infindável do mesmo em embalagens novas, assombrada por sua própria aparência e existência. "Era também claro que, apesar de o rebelde histórico ter feito sua rebelião contra a variedade metafísica de escravidão, ele a fizera em nome de uma escravidão nova e aprimorada" 49.

Kierkegaard afirma que "A raça humana deixou de temer a Deus. Depois disso, veio o castigo: passou a temer a si mesma, a ansiar pelo fantasmagórico, e agora treme diante dessa criatura de sua própria imaginação" ${ }^{50}$, ou seja, o antes escravo dos deuses, agora é escravo de si mesmo.

Há dois níveis de vida do ser humano - a dimensão Bios e a dimensão Zoe. Bios, como a palavra sugere, é a dimensão físico biológica individual, modo de viver a vida temporal - extensão do próprio ego. Zoe é uma dimensão além do físico, que nos atravessa a todos, Rev. Psicol Saúde e Debate. Jan., 2017:2(2):14-41. 
mas nos transcende - transcende o próprio planeta. Ser livre ou autêntico, a partir dessas perspectivas, seria, ao mesmo tempo não enfraquecer nenhuma delas, ao contrário, seria tomar o melhor das duas fontes, as quais somos chamados a venerar, cuidar e servir, em vez de possuir, dominar e submeter ${ }^{51}$. Pois o hiperinvestimento no ser meramente bios, dicotomiza-o, causando Ihe o contrário, o esvaziamento de sentido ${ }^{45}$.

O mito de Prometeu é uma trilha que ilustra a realidade de que o ser humano parece sempre estar em desequilíbrio: ora escravo das divindades, esvaziado de subjetividade, ora alienado da esfera divina, superinvestido de subjetivismo, escravo do próprio coração. Ora longe do trono, como vassalo, ora assentado nele, como soberano senhor, sem substância e tamanho para tal. Por isso, distante da sua verdadeira posição - ao lado de e não viúvo de, daí a orfandade - estar viúvo de si mesmo.

Por esta razão, o grande ato da existência humana, ao contrário do que defende Sartre - que é ser deus, deveria ser como afirma Kierkegaard:

Ousarmos ser nós próprios, ousar-se ser um indivíduo, não um qualquer, mas este que somos, sozinhos frente a Deus, isolado na imensidade de seu esforço e de sua responsabilidade: eis o heroísmo cristão ${ }^{52}$.

Ser Deus, em relação ao ser humano, se equivale a ser uma pessoa, e, é sendo uma pessoa, com todas as implicações existências, que se atinge o ápice da perfeição, pois "O segredo de nossa semelhança com Deus deve ser buscado em nossa mortalidade" 53. Fazer o caminho inverso é optar pela imperfeição, pela inautenticidade, pelo vazio e tentar preenche-lo com fumaça. Foi exatamente isso que aconteceu com os personagens do Mito ao se sentarem no trono de Deus foram reduzidos de pessoas em indivíduos 
(despersonalização) e, a partir daí, nem tudo sai como planejado - o que era céu virou inferno e o que era felicidade, a maior das tragédias - a saber, a perda do direito de poder ser infeliz.

Qual o segredo? Aceitar o vazio, sem tentar preenche-lo, pois exercer todo o poder que se dispõe e o que não se dispõe, para evita-lo é negar a própria natureza da existência; é evitar a noite escura e, por fim, tentar ser maior do que Deus, pois Deus é aquele que, de maneira voluntária, não exerceu todo o seu poder, suportando o vazio e, é exatamente nesse vazio, dentro de si mesmo, que a vida, o universo e tudo pode existir ${ }^{54}$. "Em primeiro lugar, Deus criou o céu e a terra - tudo que se vê e tudo que não se vê. A terra era como uma massa sem forma, um vazio sem fim, uma escuridão quase palpável. O Espirito de Deus pairava sobre o abismo das águas"25.

Por fim, esse vir-a-ser, que vai além do indivíduo e especialmente do individualismo narcisista e da vida organizada nos moldes socráticos, a partir da razão, é um vir a ser a partir da relação, da negação do sofisma Narcísico e de Prometeu que entronizou deuses de barro, tirando-Ihe a benção da tragédia, o que alimentou mais o ódio do que a admiração pelo eu e, por fim a incapacidade de sentir as coisas, as pessoas e principalmente a si mesmo ${ }^{45}$.

O trágico é, sim, a transfiguração do sofrimento ou do modo de intensificação da vida. Portanto, aquele que crê na vida não é de modo algum um pessimista ou fugidio. Isso, porque o sentimento trágico da vida é antes a aceitação da própria vida em tudo o que ela oferece, tanto de medonho, de decadente, de perecível, de morte, quanto de sedutor, de pulsante, de delirante e de divino ${ }^{34}$.

Por fim, a tragédia não é a destruição do que não possui valor, ao contrário, só é tragédia aquilo que demanda a perda ou a construção, com sofrimento, do que possui valor inestimável, a existência. Assim, encare a vida e ela sorrira de volta, negue-a ou vire as costas e ela tramará seu fim prematuramente.

Rev. Psicol Saúde e Debate. Jan., 2017:2(2):14-41. 


\section{CONSIDERAÇÕES FINAIS}

Ao olhar para o Mito de Prometeu como trilha, com suas imagens simbólicas, foi possível perceber nuances histórico-filosóficas da orfandade existencial. Fenômeno que não é exclusividade do tempo presente. Trata-se de um processo longo e perene e nem tudo é negativo, muitos ganhos podem ser vistos: mais oportunidades, igualdade e acesso a uma vida mais abundante, por exemplo.

Contudo a escassez de substância subjetiva veio no bojo dos ganhos e despersonalizou as pessoas. Na contramão do que se esperava, a abundância anestesiou e corrompeu o ser, convencendo-o de que é o que possui, mas tudo perde o valor quando há abundância, inclusive a própria existência.

Assim, se a lógica estivesse certa - de que uma vida abundante, sem a consciência de que viver é angustiar e o angustiar-se forma e fortalece a existência, o mundo deveria estar marcado por vidas plenas e felizes. Isso seria ótimo, se fosse totalmente verdadeiro.

Entretanto, a reflexão aponta outra realidade - a de que, em grande medida, o ser humano se encontra despido de si mesmo à procura de cessar a angústia que esse vazio gerou. O consumo já não dá mais conta. O prazer estagnou-se.

Ironicamente, a conta parece ainda recair sobre a religião, mesmo que há muito se negue sua eficácia e Deus tenha sido destronado do cotidiano e da vida. Surge a mágica proposta pela nova religião, a tecnologia, com suas profecias que carecem de cumprimento, pois de um upgrade a outro, revela-se com pouco ou quase nenhuma transformação efetiva, no existente, ao contrário.

Há uma onda de triunfalismos regada pelo grande desenvolvimento científico e tecnológico que ignora o caos interno das pessoas. A sociedade contemporânea não parece estar totalmente consciente dessa fragilidade de seus protagonistas. A cidade incumbiu-se do papel duplo de proteger e expor todas as mazelas desse ser que se encontra mais em desconstrução do que em construção. Que trafega pela vida, trôpega e cegamente, de prazer em prazer.

Rev. Psicol Saúde e Debate. Jan., 2017:2(2):14-41. 
Portanto, se o olhar estiver voltado apenas para as exterioridades e as conquistas e avanços científicos-tecnológicos, que se tornou comum na contemporaneidade, a conclusão fácil e rápida é a de que se alcançou o ápice das realizações. Isso é como olhar um quadro de longe para não perceber as fissuras e as falhas que compõem a obra.

Talvez seja pessimista demais dizer que a perda da tragicidade da vida enfraqueceu e enclausurou o ser humano na imanência, impedindo-o de alcançar um nível maior de maturidade, mas longe disso, a proposta é exatamente o contrário.

Negar a posologia da tragédia, na vida, é negar a própria existência. É viver cegamente a reboque das ondas de prazer fabricado, e por fim, se tornar inquilino dentro do próprio ser, caminhando contra a vida, na borda do ser vazio, oco, à beira do precipício do suicídio.

\section{REFERÊNCIAS}

1. Strong J. Dicionário Bíblico Strong. Tamboré Barueri, SP: Sociedade Bíblica do Brasil; 2002.

2. Faria E. Dicionário Escolar Latino-Portugues. 4ª Rio de Janeiro: Ministério da Educação e Cultura; 1967.

3. Pereira C, Filho P. A compreensão da existência como possibilidade a partir da filosofia existencial de Soren Kierkegaard. Revista Húmus. 2014:4(10):86-92.

4. Peterson E. Histórias gregas e orações Hebreias. In: Peterson E. Um pastor segundo o coração de Deus: a forma da integridade pastoral. Traduzido por Cláudia Moraes Ziller. Rio de Janeiro: Textus; 2000. 21-40 p.

5. Ravazi G. O Mito de Prometeu: acordos e desacordos entre Sócrates e Protágoras. Pólemos. 2014:3(5):155-167.

6. Paula A, Marques V, Gontijo E. Angústia na Contemporaneidade: uma leitura de Freud e Kierkegaard. CliniCAPS. 2013:7(19).

7. Batista M. Frans Kafka e a angústia Kierkegaardiana. Revista de Estudos Filosóficos. 2011:6:131-149.

8. Martin H. O ser e o tempo - Coleção Pensamento Humano. $5^{\mathrm{a}}$ Ed. Petrópolis - RJ: Rev. Psicol Saúde e Debate. Jan., 2017:2(2):14-41. 
Vozes; 2006.

9. Santos D. O sentido existencial da angustia. In "obras completas" Vol. II, p. 153-165. Lisboa: Fundação Calouste Kulbekian; 1982.

10. Kierkegaard S. O conceito de angústia. São Paulo: Hemus; 1968.

11. Amaral A. Educação e psicanálise e seus campos de atuação. Acta Científica. 2010:2(2):79-85.

12. Silveira N. Uma mulher de muita vivência e que tem a idade das ilusões. Psicol ciênci prof. 1994:14(1-3).

13. Boff L. Saber cuidar: ética do humano. Petrópolis: Vozes; 1999.

14. Moraes E. Os relâmpagos da fatalidade. Inquietude. 2013;4(12):48-67.

15. Lesky A. A tragédia grega. São Paulo: Perspectiva; 2006.

16. Campos M. Memória, passagens e permanência da tragédia na literatura alemã. Pandaemonium Ger. 2010:2(16):138-154.

17. Kierkegaard S. O desespero Humano (Doença até a morte). Os pensadores. Tradução: Adolfo Casais Monteiro. São Paulo: Abril Cultural; 1974.

18. Almeida, J, Redyson D. Mediação ou paradoxo: Kierkegaard leitor de Hegel. Rev Pandora Bras. 2010:(23):102-113.

19. Farago F. Compreender Kierkgaard. Petrópolis: Vozes; 2006.

20. Macêdo K. O desamparo do indivíduo na modernidade. Ecos. 2(1):94-107.

21. May R. O homem à procura de si mesmo. 8a. Petrópolis - RJ: Editora Vozes; 1980.

22. Teixeira J. Problemas psicopatológicos contemporâneos: uma perspectiva existencial. 2004: 24(3)405-413.

23. Bowra C. A experiencia grega. Lisboa: Arcádia; 1967.

24. Dainez D, Smolka A. O conceito de compensação no diálogo de Vigotski com Adler: desenvolvimento humano, educação e deficiência. Educ Pesqui. 2014:40(4):1093-1108.

25. Peterson E. A mensagem: Bíblia em linguagem contemporânea. São Paulo: Editora Vida; 2011.

Rev. Psicol Saúde e Debate. Jan., 2017:2(2):14-41. 
26. Erculino N. Deus em Sartre: Má-fé e Aspiração. Rev Pág de Filo. 2013:5(1):17-44.

27. Vicente C. A epistemologia anarquista de Feyerabend e a nova comunicação: diálogos na contrução de um aplicativo. Acta Científica. 2014;6(VI):161-177.

28. Dutra E. Suicídio de universitários: o vazio existencial de jovens na contemporaneidade. Estud e Pesqui em Psicol. 2012 Sep 1:12(3):924-937.

29. Magalhães, Marília, Melo S. Morte e Luto: o sofrimento do profissional da saúde. Psicologia e Saúde em Debate. 2015:1(1):65-77.

30. Garcia-Rosa L. Freud e o incosciente. 24a . Rio de Janeiro: Jorge Zahar; 2009.

31. Janouch G. Conversas com Kafka. Rio de Janeiro: Nova Fronteira; 1983.

32. Dias R. Shopenhauer e a Arte. In: Os Filósofos e a Arte (Org. de Rafaqel HaddockLobo). Rio de Janeiro: Rocco; 2010.

33. Nietzsche F. O Nascimento da Tragédia. São Paulo: Escala; 2001.

34. Marins I. Um olhar sobre o perspectivismo de Nietzsche e o pensamento trágico. Rev Trágica Estud sobre Nietzsche. 2008:1(2):124-141.

35. Nietzsche F. Aurora: reflexões sobre os pensamentos morais. Trad. Paulo César Souza. São Paulo: Companhia das Letras; 2004.

36. Santi P. Consumo e desejo na cultura do narcisismo. Comun mídia e Consum. 2005:2N. 5P:173-204.

37. Bittencourt R. Os delírios urbanos e os signos extáticos da cidade. Rev Húmus. 2014:(10):33-54.

38. Caniato A, Nascimento M. A subjetividade na sociedade de consumo: do sofrimento narcísico em tempos de excesso e privação. Arq Brasi Psicolo. Psicolo. 2010:62(2):25-37.

39. Claudia A, Martins A. A angústia de viver na cidade / The Anguish of Living in the City. Bakhtiniana, Rev Estud Discurso. 2015:10(1):156-175

40. Lins P. Cidade de Deus. Segunda Ed. São Paulo, SP: Companhia das Letras; 1997.

41. Costa J, Caetano R. Revista Igarapé Literatura, Educação e Cultura: Caminhos da Alteridade. Rev Eletrônica Igarapé. 2014:(3):195-210.

42. Tillich P. A concepção do homem na filosofia existencial. Rev da Abordagem 
Gestáltica XVI. 2010:2:229-234.

43. May R. A psicologia e o dilema humano. Petrópolis: Vozes; 2000.

44. Lúcia M, Romera C. O Encantamento como possibilidade de conhecimento e as vicissitudes do real. Psicologia e Saúde em Debate. 2015:1(2):55-70.

45. Sennett R. Narciso ou a estratégia do vazio. 2005;

46. Alves R. Ostra feliz não faz pérola. São Paulo: Editora Planeta do Brasil; 2008.

47. Gouvêa R. Paixão pelo paradoxo: uma introdução à Kierkegaard. São Paulo: Novo Século; 2000.

48. Lipovetsky G. A Felicidade paradoxal: ensaio sobre a sociedade de hiperconsumo. São Paulo: Companhia das Letras; 2007.

49. Pallares-Burke M. Entrevista com Zigmunt Bauman. Tempo Social - USP. 2004:16(1):301-325.

50. Paul Stratern. Kierkegaard. Rio de Janeiro: Jorge Zahar; 1999.

51. Melloni J. Hacia un tiempo de síntesis. Barcelona: Fragmenta; 2011:4.

52. Ramon S. A psicoterapia dialógica de Martin Buber. Psico PUCRS.2010:41(4):534541.

53. Clara M, Bingemer L, Rio PUC. O Deus inocentre e a mortalidade humana. Cruz e salvação em Somone Weil. Sintese Nova Fase. Belo Horizonte. MG; 1994:21(64):113-124. 54. Weil S. Espera de Deus. São Paulo, ECE, 1987: Ed. Portuguesa: Lisboa, Assírio \& Alvim; 2005.

Rev. Psicol Saúde e Debate. Jan., 2017:2(2):14-41. 